\title{
OPEN Gene expression and morphological responses of Lolium perenne L. exposed to cadmium $\left(\mathrm{Cd}^{2+}\right)$ and mercury $\left(\mathrm{Hg}^{2+}\right)$
}

\author{
Yuby Cruz ${ }^{1}$, Sharik Villar ${ }^{2}$, Karen Gutiérrez ${ }^{2}$, Carolina Montoya-Ruiz ${ }^{2,3}$, Jorge L. Gallego ${ }^{4}$, \\ Maria del Pilar Delgado² \& Juan F. Saldarriaga ${ }^{1 \otimes}$
}

Soil contamination with heavy metals is a major problem worldwide, due to the increasing impact mainly caused by anthropogenic activities. This research evaluated the phytoremediation capacity of, Lolium perenne for heavy metals such as cadmium $\left(\mathrm{Cd}^{2+}\right)$ and mercury $\left(\mathrm{Hg}^{2+}\right)$, and the effects of these metals on morphology, biomass production, and the changes on gene expression. Seeds of $L$. perenne were exposed to six concentrations of $\mathrm{Cd}^{2+}$ and $\mathrm{Hg}^{2+}$ in the range of 0 to $25 \mathrm{mg} \mathrm{L}^{-1}$, and two mixtures of $\mathrm{Cd}^{2+}-\mathrm{Hg}^{2}$. The Non-Observed Effect Level (NOEL) was established with dose response curves and the expression of specific genes was evaluated applying a commercially available quantitative reverse transcription (RT-qPCR) assay. There was no significant effect when exposing the seeds to $\mathrm{Hg}^{2+}$, for $\mathrm{Cd}^{2+}$ the maximum concentration was established in $0.1 \mathrm{mg} \mathrm{L}^{-1}$, and for the two concentrations of mixtures, there was a negative effect. An increase of expression of genes that regulate antioxidant activity and stress was found when the plant was exposed to heavy metals. Given the high tolerance to metals analyzed that was reflected both, the development of the plant and in its molecular response, these results highlight that $L$. perenne is a plant with phytoremediator potential.

Soil contamination with heavy metals has become an important environmental problem worldwide, because of their high toxicity for the ecosystems and human health, even in small doses ${ }^{1-3}$. The increase of heavy metal contamination is mainly caused by anthropogenic activities such as mining, agriculture, industrialization, and urbanization $^{4-7}$. In particular, this is a critical issue on developing countries, where the need of economic growth overtake the rules of environmental protection, being the priority to look strategies to repair or mitigate the environmental damage ${ }^{2}$.

Cadmium $(\mathrm{Cd})$ and mercury $(\mathrm{Hg})$ are the principal heavy metals that have been increasing their concentration in soils due to anthropogenic activities ${ }^{8}$. It is estimated that the natural concentration of cadmium in soils is between 0.1 and $1.0 \mathrm{mg} / \mathrm{kg}$ while the highest concentration is around $10 \mathrm{mg} / \mathrm{kg}$. While for mercury, concentrations between 0.11 and $36.9 \mathrm{mg} / \mathrm{kg}$ have been reported in mining soils in Colombia ${ }^{9,10}$. The increasing of inorganic cadmium $\left(\mathrm{Cd}^{2+}\right)$ in soils is mainly generated by the used of phosphate fertilizers in the agriculture and the oil refinery ${ }^{11,12}$. The increase of mercury ions $\left(\mathrm{Hg}^{2+}\right)$ is generated by the amalgamation of gold typically used in illegal mining ${ }^{13}$. Aimed to reduce the concentration of heavy metals in soils, diverse strategies have been implemented based on chemical, physical and biological processes ${ }^{14}$. The phytoremediation is one the biological process that reduces the concentrations of heavy metals through the growing of plants, which absorb, transfer, or transform the metal, this process is considered cost-effective and environmentally friendly ${ }^{14,15}$.

Within the phytoremediator plants, Lolium perenne (ryegrass) is a bunchgrass native of temperate regions of Europe, Asia, and North Africa, and it is widely distributed throughout the world, including America, and Australia $^{16,17}$. The responses of this plant when exposed to abiotic stress are known at the morphological and cellular level. However, information on the effects in relation to dose-time and molecular activity is scarce ${ }^{18-20}$. Regarding the morphological response, a promising result has been found in the plant characterized by rapid

\footnotetext{
${ }^{1}$ Department Civil and Environmental Engineering, Universidad de los Andes, Carrera 1Este \#19A-40, Bogotá, Colombia. 'Department Biological Sciences, Universidad de los Andes, Carrera 1 \#18A-10, Bogotá, Colombia. ${ }^{3}$ Facultad de Ciencias, Universidad Nacional de Colombia, Sede Medellín Calle 59A \#63-20, Medellín, Colombia 050034. "Environmental Research Group (GIA), Department Engineering, Fundación Universitaria Tecnológico Comfenalco, Carrera 44 D \# 30A-91, 130015 Cartagena, Colombia. ${ }^{\varpi}$ email: jf.saldarriaga@ uniandes.edu.co
} 
germination, root development, sensitivity to metals (no mercury transformation), resistance to environmental stress, and wide distribution ${ }^{18,19,21}$. In contrast, information is scarce on the adaptation mechanisms of $L$. perenne. This information is necessary, because one of the first signs of adverse effects that occur in organisms exposed to stress conditions is an alteration in gene expression that reflects physiological changes to adapt to new unfavorable conditions ${ }^{22}$.

It has been demonstrated that $L$. perenne can tolerate high salinity conditions through molecular interactions involving genes related to the enzymatic antioxidant system, activation of shock thermic stress proteins, mitochondrial metabolism, among others ${ }^{23}$. The activation of the enzymatic antioxidant system in the cell is one of the molecular mechanisms during the plant exposure to heavy metals. However, the production of reactive oxygen species (ROS) increases, and could lead lipid peroxidation, membrane damages, and enzyme inactivation ${ }^{4}$. This system involves different enzymes such as catalase (CAT), peroxisomal ascorbate peroxidase (pAPX), glutathione reductase (GR), glutathione S-transferase (GST), glutathione peroxidase (GPX), superoxide reductase (SOD), and non-enzymatic substances production as ascorbic acid, $\alpha$-tocopherol, and carotenoids ${ }^{24}$.

Most of the early responses to metal toxicity are mediated by the induction of heat shock proteins as Hsp70 and Hsp90, which are chaperons that are activated in any stress condition to promote the homeostasis in plant cells ${ }^{25}$. Hsp90 protein are responsible for safeguarding the integrity of the cell membrane when a plant organism is exposed to heavy metals, resulting in reductions in the rate of root germination and length ${ }^{26}$. Hsp70 perform the catalysis necessary to recruit and release proteins quickly ${ }^{26,27}$.

On the other hand, the hormetic-growth could be due by effects in photosynthesis and respiration routes. Light-harvesting chlorophyll a/b-binding protein (Lhcb1), serves as a complex antenna, transferring the energy obtained from the absorption of sunlight to photosystem II, to boost electron transport in photosynthesis. Succinate dehydrogenase flavoprotein subunit-mitochondrial precursor (SDH) is an essential part of the Krebs cycle and plant respiration. Previous evidences show that the genes that encodes for these proteins has been modulated during L. perenne growth on high salinity soil conditions ${ }^{23}$.

According to the lack of knowledge about the mechanisms used by L. perenne to grow in soil contaminated with heavy metals, the few information about growth during the time, and the necessity to find environmentally friendly strategies to remediated soil that has been contaminated with metals like cadmium and mercury. This study evaluated the phytoremediation capacity of $L$. perenne for $\mathrm{Cd}^{2+}$ and $\mathrm{Hg}^{2+}$ contamination, the germination kinetics and growth, and the changes in the expression of the genes associated to the enzymatic antioxidant system, activation of shock thermic stress protein, and mitochondrial metabolism.

\section{Experimental}

Growth of Lolium perenne. Lolium perenne seeds reference Rye Grass Bestfort plus (X CEBA, Bogotá, Colombia) were washed with deionized water and $10 \% \mathrm{KOH}$ placed in Petri dishes $(10 \mathrm{~cm}$ in diameter and $2.5 \mathrm{~cm}$ deep) with Whatman $0.2 \mathrm{~mm}$ filter paper. Each Petri dish was watered with $7 \mathrm{ml}$ of $\mathrm{Cd}^{2+}$ or $\mathrm{Hg}^{2+}$ solution at concentrations of $0.05,0.10,0.25,1.00,5.00$ and 25.00 , which were selected according to previous studies and the actual concentrations reported in contaminated soils ${ }^{28,29}$. Binary mixtures of $\mathrm{Cd}^{2+}-\mathrm{Hg}^{2+}$ were also evaluated at concentrations of 0.1 and $0.25 \mathrm{mg} / \mathrm{L}$ randomly selected within the range previously reported ${ }^{28,29}$. $\mathrm{The}^{\mathrm{Cd}^{2+}}$ solution was prepared by diluting $\mathrm{CdCl}_{2}-2.5 \mathrm{H}_{2} \mathrm{O}$ (Alfa Aesar, Hampton, USA) in deionized water, and the $\mathrm{Hg}^{2+}$ solution diluting $\mathrm{HgCl}_{2}$ (Sigma-Aldrich, San Luis, USA). The seeds were exposed in a $12 \mathrm{~h} / 12 \mathrm{~h}$ photoperiod with temperatures of $20 / 16^{\circ} \mathrm{C}$ (light/day) and relative humidity of $52 \%$. The cultures were observed daily and if necessary were moistened with $3 \mathrm{ml}$ of the corresponding solution. Seed boxes watered with distilled water was included as negative controls. According to Decree 309 of 2000 in Colombia, study permits are not necessary if collections or captures will not be carried out, and the research has focused on the sowing of seeds acquired by the researchers.

Determination of morphological changes. Germination. For the germination test, 60 seeds were added to each Petri dish, and they were grown as mentioned above. The number of germinated seeds were counted daily for each of the concentrations of $\mathrm{Cd}^{2+}, \mathrm{Hg}^{2+}$ and $\mathrm{Cd}^{2+}+\mathrm{Hg}^{2+}$ until day nine, time when the maximum percentage of germination was achieved, this time was determined by doing a preliminary germination test with the control. Four replicates of the culture were made for each treatment and for the control. With the obtained data, the final germination percentage (FGP), initial germination percentage (IGP), the germination speed coefficient (CVG), the average germination time (MGT), and the germination rate index (TGI) was established according to the methodology proposed by Al-Ansari and Ksiksi ${ }^{30}$.

Elongation parameters. To evaluate the effect on elongation, the cultures were made with the same conditions and replicates as in the germination test. Roots elongation was measured daily ${ }^{31}$ by photography register using the software Image J (NIH, USA). On the surface of each of the Petri dishes, a $5 \times 5$ grid was marked, forming 25 squares of $1 \mathrm{~cm}$, in each of these squares a seed was placed. To evaluated elongation at the end point, on day 9 after seed sowing the length of the root and stem were measured using a PCE-DCP $600 \mathrm{~N}$ Vernier caliper (HOPEX, Colombia) with an accuracy of $0.01 \mathrm{~mm}$.

Evaluation of gene expression. Lolium perenne seeds were grown in concentrations of 0.05 and $0.1 \mathrm{mg} / \mathrm{L}$ of $\mathrm{Cd}^{2+}$ and $\mathrm{Hg}^{2+}$ and 0.1 and $0.25 \mathrm{mg} / \mathrm{L}$ for the binary mixture, which correspond to the toxicity threshold (NOEL). Also, a negative control without contaminant was grown. On day 9 of sowing the seeds, roots and stems were cut using sterile scalpels and were collected in sterile $1.5 \mathrm{~mL}$ Eppendorf tubes to be stored at $-80^{\circ} \mathrm{C}$ until the subsequent RNA isolation. For this procedure approximately 50-150 mg of tissue were used, it was macer- 


\begin{tabular}{|c|c|c|c|c|}
\hline Name & Direction & Sequence & Size $(\mathbf{p b})$ & Temperature annealing $\left({ }^{\circ} \mathrm{C}\right)$ \\
\hline \multirow{2}{*}{ HSP70 } & $\left(5^{\prime}-3^{\prime}\right)$ & TCTTGGCGATGATGGGGTTGC & \multirow{2}{*}{220} & \multirow{2}{*}{61} \\
\hline & $\left(3^{\prime}-5^{\prime}\right)$ & GACTCGAAGAACGCCCTGGAG & & \\
\hline \multirow{2}{*}{ HSP90 } & $\left(5^{\prime}-3^{\prime}\right)$ & CTGCTCCTTGCTGCTTCCCG & \multirow{2}{*}{211} & \multirow{2}{*}{60} \\
\hline & $\left(3^{\prime}-5^{\prime}\right)$ & GGGACAGTATGCCAAGTTCTGGA & & \\
\hline \multirow{2}{*}{$p A P X$} & $\left(5^{\prime}-3^{\prime}\right)$ & AGAGGATCACGGGTCCATGCAC & \multirow{2}{*}{152} & \multirow{2}{*}{62} \\
\hline & $\left(3^{\prime}-5^{\prime}\right)$ & GATGCTAAGAGAGGGGCACCAC & & \\
\hline \multirow{2}{*}{ CAT } & $\left(5^{\prime}-3^{\prime}\right)$ & GCAAGAACCACAGCCACGCCA & \multirow{2}{*}{153} & \multirow{2}{*}{62} \\
\hline & $\left(3^{\prime}-5^{\prime}\right)$ & CCTCGGGCCAGGTCTTGGT & & \\
\hline \multirow{2}{*}{ GST } & $\left(5^{\prime}-3^{\prime}\right)$ & CTACAGAGCCACGCCGTCATCG & \multirow{2}{*}{193} & \multirow{2}{*}{62} \\
\hline & $\left(3^{\prime}-5^{\prime}\right)$ & CAGCGTGGATCTGGGGTGCT & & \\
\hline \multirow{2}{*}{$M T P B-1$} & $\left(5^{\prime}-3^{\prime}\right)$ & CGCATGCCATTGGAGAATCACT & \multirow{2}{*}{219} & \multirow{2}{*}{60} \\
\hline & $\left(3^{\prime}-5^{\prime}\right)$ & GCAAAATAGCCAGCACCTTCCT & & \\
\hline \multirow{2}{*}{ SDHA } & $\left(5^{\prime}-3^{\prime}\right)$ & TGAACCCACTGGATGATGAA & \multirow{2}{*}{111} & \multirow[t]{2}{*}{55} \\
\hline & $\left(3^{\prime}-5^{\prime}\right)$ & GGACAAAATTCAGGGGAAGC & & \\
\hline \multirow{2}{*}{ Lhcb-1 } & $\left(5^{\prime}-3^{\prime}\right)$ & TTCTCCATGTTCGGCTTCTT & \multirow{2}{*}{227} & \multirow{2}{*}{61} \\
\hline & $\left(3^{\prime}-5^{\prime}\right)$ & TCCATCAGTCACGACACACA & & \\
\hline \multirow{2}{*}{$T B P-1$} & $\left(5^{\prime}-3^{\prime}\right)$ & GCAGATATTCTTGATCCCGCTTT & \multirow{2}{*}{69} & \multirow{2}{*}{60} \\
\hline & $\left(3^{\prime}-5^{\prime}\right)$ & CGGATGAGGGAACTCAATCTTT & & \\
\hline
\end{tabular}

Table 1. Information of selected primers.

ated using liquid nitrogen and then processed using Agilent Plant RNA Isolation Mini Kit (Agilent Technologies, USA), according to the manufacturer's recommendations.

Isolated RNA was quantified using Nanodrop and its integrity confirmed by a $1.5 \%$ agarose gel stained with GelRed (Biotium, Fremont, USA). The extracted RNA was treated with DNAse (Thermo scientific, Waltham, USA) and each sample was diluted to a concentration of $30 \mathrm{ng} / \mu \mathrm{l}$ for processing. This assay was performed by duplicate for each treatment concentrations and the negative control.

The genes evaluated were selected according to the previously reported sequences and their evidence in their participation in tolerance processes of the plant response to growth in contaminated soils ${ }^{23}$. These genes encode for proteins involved in detoxification routes: $C A T$ gene coding for catalase, $p A P X$ gene for enzymatic ascorbate peroxidase, GST for glutathione S-transferase protein, MTPB-1 coding for metal tolerance protein B. In stress-associated routes: HSP70 encoding for heat shock protein 70 and HSP90 encoding for heat shock protein 90 . Those are involved in the carbohydrate metabolism routes: SDHA encodes a major catalytic subunit of succinate-ubiquinone oxidoreductase, and the $L h c b-1$ gene encodes chlorophyll-binding protein a/b type 1 .

The determination of its differential expression was carried out by quantitative PCR using the Brilliant III Ultra-Fast SYBR Green RT-qPCR Master Mix kit (Agilent, USA). For the PCR reaction $2 \mu$ of RNA was added following the manufacturer's recommended protocol. The reactions were carried out by duplicate $(n=2)$ on the $\mathrm{Mx} 3000 \mathrm{P}$ thermal cycler (Agilent, Santa Clara, USA), and if the obtained $\mathrm{C}_{\mathrm{T}}$ differed more than $5 \%$ the reaction was processed again. The temperature profile was $50{ }^{\circ} \mathrm{C}$ for $10 \mathrm{~min}$, denaturation at $95{ }^{\circ} \mathrm{C}$ for $3 \mathrm{~min}, 40 \mathrm{ring}$ cycles and extension of $95^{\circ} \mathrm{C}$ for $20 \mathrm{~s}$ and $55^{\circ} \mathrm{C}$ to $62^{\circ} \mathrm{C}$ for other $20 \mathrm{~s}$ (Table 1). At the end of each run, the melting curves were produced to verify the specific amplification of the reaction, the temperature profile used for this curve was $95^{\circ} \mathrm{C}$ for $1 \mathrm{~min}, 55^{\circ} \mathrm{C}$ for $30 \mathrm{~s}$ and $95^{\circ} \mathrm{C}$ for $40 \mathrm{~s}$. Also, the specificity of the amplification was verified through $1.5 \%$ agarose gel stained with GelRed fluorescent (Biotium, Fremont, USA). The expression was quantified by the delta threshold cycle $\left(\mathrm{C}_{\mathrm{T}}\right)$ method, using TBP-1 (which encodes for TATA-box-binding protein) as the constitutive gene (Table 1) taking into account a corrected efficiency for all reactions of $1.8^{32,33}$.

Data analysis. For the germination and elongation data, the dose response curve was determined, and the toxicity threshold was calculated, defined as the maximum concentration which there is no significant effect (NOEL). In order to determine the ideality of the curve, the normality of the data was evaluated using the Anderson Darling test and subsequently, a parametric or non-parametric ANOVA was performed depending on the data obtained. Likewise, comparisons were made to assess the differences in germination and elongation between treatments with the Kruskal-Wallis or Dunn's tests depending on the normality of the data. To evaluate the effect of the interaction between the exposure time and the metal concentration, a general linear model (GLM) was performed, where exposure time and metal concentration were included as factors. The software used for the statistical analysis was GraphPad Prism 5.0 and Minitab 2018.

\section{Results}

Preliminary determination of germination optimal time and seed viability. The cumulative germination rate of the L. perenne seeds is shown in Fig. 1. It follows a typical S or sigmoidal curve behavior. Likewise, it was found that the emergence of the radicular structure started on average on the fourth day, and it was stabilized on day seven with a percentage of $75 \%$ without statistically significant changes for the following two days of observation $(P=0.405)$. To determine the optimal time, the last day of exponential growth was consid- 


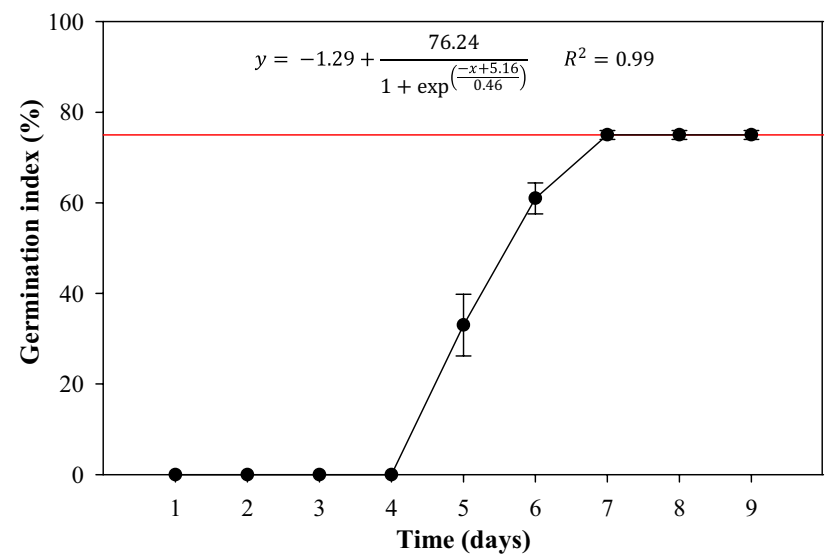

Figure 1. Average germination percentage of L. perenne seeds.
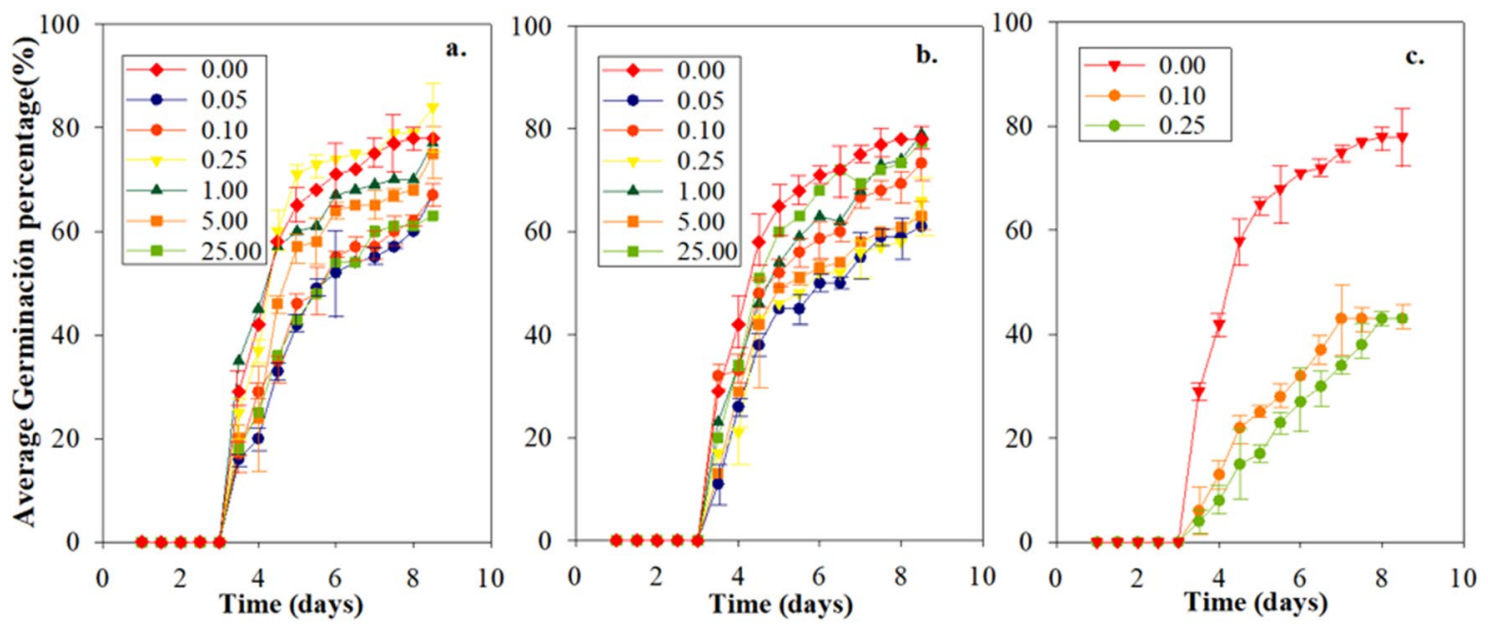

Figure 2. Germination percentages of L. perenne exposed to de different metal concentrations. (a) $\mathrm{Cd}^{2+},(\mathbf{b})$ $\mathrm{Hg}^{2+},(\mathbf{c}) \mathrm{Cd}^{2+}-\mathrm{Hg}^{2+}$.

ered, this because until this day the growth of mature seeds is presented and with the necessary characteristics to continue growing even under stressful conditions.

The curve found is similar to the one obtained by Bewley et al. ${ }^{34}$ who argues that this type of curve is obtained when the seed sample is not uniform, which causes some seeds to complete germination relatively quickly and others require longer times. These cumulative germination curves are normally sigmoidal, typically occurring when dry, viable seeds begin water absorption and a series of events are triggered that end with successful germination ${ }^{35-37}$. The foregoing reflects that, like many of the biological properties, the germination time of the seeds presents approximately a normal distribution. Likewise, that the germination percentage has stabilized at a value less than $100 \%$, and that after three days there have been no increases, implies that only a fraction of the selected sample was able to germinate under imbibition conditions, for which the remaining fraction of approximately $24 \%$ corresponded to unviable seeds.

Lolium perenne germination under $\mathrm{Cd}$ and $\mathrm{Hg}$ exposure. The germination rate was reported daily for nine days, taking two measurements per day (Fig. 2). For the concentrations of $\mathrm{Cd}^{2+}$ (Fig. 2a) and $\mathrm{Hg}^{2+}$ (Fig. 2b), a germination process like that of Fig. 1 was presented. In contrast, for the binary mixture $\left(\mathrm{Cd}^{2+}-\mathrm{Hg}^{2+}\right)$ a delay in the stabilization time was observed, as well as a decrease in the percentage of germination on the last day (Fig. 2c).

Although germination started on the same day for all treatments, the number of germinated seeds showed variations between the concentrations for the different metals. For the control seeds, a percentage of germination of $29 \pm 2.51 \%$ was presented after the first day. In the case of seeds treated with each of the concentrations of the different metals, a decrease in the germination percentage was observed. According to the Kruskal Wallis test, a significant difference with a $P$-value $<0.05$ was shown for $\mathrm{Cd}^{2+}, \mathrm{Hg}^{2+}$ and $\mathrm{Cd}^{2+}-\mathrm{Hg}^{2+}$ in comparison with the control. 


\begin{tabular}{|l|l|l|l|l|l|l|}
\hline Treatment & Concentration $(\mathbf{m g} / \mathbf{L})$ & IGP $(\%)$ & FGP $(\%)$ & CVG $\left(\right.$ day $\left.^{-1}\right)$ & MGT (day) & TGI \\
\hline \multirow{5}{*}{$\mathrm{Cd}^{2+}$} & 0.05 & $16.00 \pm 1.63$ & $67.00 \pm 6.81$ & $0.15 \pm 0.00$ & $4.91 \pm 0.12$ & $0.56 \pm 0.05$ \\
\cline { 2 - 7 } & 0.10 & $17.00 \pm 3.42$ & $67.00 \pm 3.79$ & $0.16 \pm 0.00$ & $4.58 \pm 0.22$ & $0.57 \pm 0.04$ \\
\cline { 2 - 7 } & 0.25 & $25.00 \pm 9.15$ & $84.00 \pm 4.32$ & $0.16 \pm 0.00$ & $4.67 \pm 0.26$ & $0.77 \pm 0.07$ \\
\cline { 2 - 7 } & 1.00 & $35.00 \pm 8.54$ & $77.00 \pm 6.61$ & $0.16 \pm 0.00$ & $4.59 \pm 0.15$ & $0.73 \pm 0.07$ \\
\cline { 2 - 7 } & 5.00 & $20.00 \pm 6.73$ & $75.00 \pm 7.90$ & $0.15 \pm 0.00$ & $4.93 \pm 0.24$ & $0.65 \pm 0.07$ \\
\cline { 2 - 7 } & 25.00 & $18.00 \pm 4.76$ & $63.00 \pm 4.76$ & $0.15 \pm 0.00$ & $4.81 \pm 0.25$ & $0.56 \pm 0.01$ \\
\hline$P$-value & & 0.58 & 0.35 & 0.90 & 0.74 & 0.07 \\
\hline \multirow{5}{*}{$\mathrm{Hg}^{2+}$} & 0.05 & $11.00 \pm 1.00^{*}$ & $61.00 \pm 7.00$ & $0.15 \pm 0.01$ & $5.19 \pm 0.25$ & $0.53 \pm 0.06$ \\
\cline { 2 - 7 } & 0.10 & $32.00 \pm 1.63$ & $72.00 \pm 1.33$ & $0.17 \pm 0.01$ & $5.01 \pm 0.37$ & $0.64 \pm 0.04$ \\
\cline { 2 - 7 } & 0.25 & $17.00 \pm 6.40$ & $66.00 \pm 6.83$ & $0.15 \pm 0.01$ & $5.13 \pm 0.17$ & $0.57 \pm 0.08$ \\
\cline { 2 - 7 } & 1.00 & $23.00 \pm 3.42$ & $79.00 \pm 5.00$ & $0.15 \pm 0.00$ & $5.08 \pm 0.16$ & $0.70 \pm 0.03$ \\
\cline { 2 - 7 } & 5.00 & $13.00 \pm 5.74^{*}$ & $63.00 \pm 3.42$ & $0.15 \pm 0.00$ & $4.74 \pm 0.33$ & $0.56 \pm 0.03$ \\
\hline$P$-value & & $20.00 \pm 6.32$ & $60.00 \pm 11.62$ & $0.17 \pm 0.01$ & $4.66 \pm 0.26$ & $0.68 \pm 0.10$ \\
\hline \multirow{2}{*}{$\mathrm{Cd}^{2+}-\mathrm{Hg}^{2+}$} & 0.10 & 0.02 & 0.16 & 0.43 & 0.21 & 0.12 \\
\cline { 2 - 7 } & 0.25 & $6.00 \pm 1.34^{*}$ & $43.00 \pm 1.80^{*}$ & $0.19 \pm 0.00^{*}$ & $5.12 \pm 0.02^{*}$ & $0.35 \pm 0.00^{*}$ \\
\hline$P$-value & & $4.00 \pm 0.65^{*}$ & $43.00 \pm 2.33^{*}$ & $0.17 \pm 0.00^{*}$ & $5.72 \pm 0.10^{*}$ & $0.32 \pm 0.00^{*}$ \\
\hline Control $^{25}$ & 0.00 & $<0.00$ & $<0.00$ & $<0.00$ & $<0.00$ & $<0.00$ \\
\hline
\end{tabular}

Table 2. Germination parameters of L. perenne exposed to $\mathrm{Cd}^{2+} \mathrm{Hg}^{2+}$ and $\mathrm{Cd}^{2+}-\mathrm{Hg}^{2+}$. The * represents the levels of concentration statistically significant.

Regarding the results of the Dunn's test, it was found that in the treatments with $\mathrm{Cd}^{2+}$ an inhibition potential was evidenced in the concentrations of $0.05 \mathrm{mg} / \mathrm{L}(\mathrm{DRM}=28.91), 0.1 \mathrm{mg} / \mathrm{L}(\mathrm{DRM}=25.55)$, and $25 \mathrm{mg} / \mathrm{L}$ $(\mathrm{DRM}=26.27)$. In the case of $\mathrm{Hg}^{2+}$ treatment, the inhibition potential was observed at concentrations of $0.05 \mathrm{mg} / \mathrm{L}(\mathrm{DRM}=29.27)$, and $0.25 \mathrm{mg} / \mathrm{L}(\mathrm{DRM}=27.82)$ corresponding to the lower germination lines in Fig. $2 \mathrm{~b}$. Finally, for the binary mixture, the inhibition potential was observed at both concentrations at $0.10 \mathrm{mg} / \mathrm{L}(38.57)$ and $0.25 \mathrm{mg} / \mathrm{L}(\mathrm{DRM}=38.12)$.

This potential of heavy metals to decrease germination is due to the fact that germination depends mainly on seed reserves, especially starch, for the supply of metabolites necessary in processes such as respiration, as well as other anabolic reactions that they can be inhibited by metals ${ }^{38,39}$.

Table 2 shows the effect of $\mathrm{Cd}^{2+}, \mathrm{Hg}^{2+}$ and $\mathrm{Cd}^{2+}-\mathrm{Hg}^{2+}$ treatments on different parameters associated with the germination of L. perenne seeds such as IGP, FGP, CVG, MGT, and TGI through analysis of variance. It was observed that for the individual metals there was only a significant difference in the IGP for $\mathrm{Hg}^{2+}$ with a concentration of $0.05 \mathrm{mg} / \mathrm{L}$ and $5.00 \mathrm{mg} / \mathrm{L}$ in which there is an inhibition compared to the control. On the other hand, in the case of $\mathrm{Cd}^{2+}-\mathrm{Hg}^{2+}$, statistically significant changes were presented for all the parameters evaluated. This indicates that for the two-mixture concertation $\left(\mathrm{Cd}^{2+}-\mathrm{Hg}^{2+}\right)$, the inhibition occurred both in the initial and final germination percentage and in the emergency kinetics.

Treatments exposed to $\mathrm{Cd}^{2+}$ did not present significant differences, which may be due that this metal prevents the absorption and movement of water by the seed ${ }^{40}$. However, this does not occur with exposure to $\mathrm{Hg}^{2+}$ that presented significant differences and the results are similar to other studies ${ }^{41}$. These results may be due to the entry of contaminated solution for the seeds exposed to $\mathrm{Hg}^{2+}$ and not for those exposed to $\mathrm{Cd}^{2+}$, which would indicate the inhibitory results for PGI in the case of $\mathrm{Hg}^{2+}$. Instead, in $\mathrm{Cd}^{2+}-\mathrm{Hg}^{2+}$, the most pronounced antagonistic effect was presented, very similar to that reported in other studies that associate it with the interaction between metals resulting from the formation of metal complexes with greater toxicity, or also with the influence it generates, one metal in binary mixtures in the adsorption of the other metal in the solution ${ }^{38,42}$.

Effects in the root and stem elongation. Root and stem elongation of L. perenne at different concentrations of $\mathrm{Cd}^{2+}, \mathrm{Hg}^{2+}$ and $\mathrm{Cd}^{2+}-\mathrm{Hg}^{2+}$ were evaluated after the ninth day on which a percentage greater than $80 \%$ of germination was reached for all treatments. Regarding the statistical analyses, it was found that for the cases of $\mathrm{Cd}^{2+}$ and $\mathrm{Cd}^{2+}-\mathrm{Hg}^{2+}$ there is a statistically significant effect $(P$-value $<0.05)$ of the concentrations in the elongation of both the root and the stem. For the treatments with $\mathrm{Hg}^{2+}$, there was no statistical difference between concentrations, therefore, there was no inhibitory or favorable effect for the seeds treated with this metal (Fig. 3).

Regarding the comparison tests, it was found that the root exposed to $\mathrm{Cd}^{2+}$ in concentrations of $0.25,5$ and $25 \mathrm{mg} / \mathrm{L}(\mathrm{q}=5.77, \mathrm{q}=4.28$ and $\mathrm{q}=8.85)$ presented a statistically significant difference. For the concentration of $0.25 \mathrm{mg} / \mathrm{L}$ a stimulation of $28.7 \%$ was found and for the two remaining concentrations it was observed and inhibitory effect. The root exposed to $\mathrm{Cd}^{2+}-\mathrm{Hg}^{2+}$ presented statistically significant differences for the concentrations of 0.10 and $0.25 \mathrm{mg} / \mathrm{L}(\mathrm{q}=9.47$ and $\mathrm{q}=9.52)$. For the stem exposed to $\mathrm{Cd}^{2+}$ the concentration with a statistically significant difference was $0.25 \mathrm{mg} / \mathrm{L}(\mathrm{q}=6.07)$ presenting a stimulation of $38.6 \%$, and for the stem exposed to $\mathrm{Cd}^{2+}-\mathrm{Hg}^{2+}$, a statistically significant difference was found for the concentrations of 0.10 and $0.25 \mathrm{mg} / \mathrm{L}(\mathrm{q}=8.06$ and $\mathrm{q}=8.39$ ) with an inhibitory effect in both concentrations. 


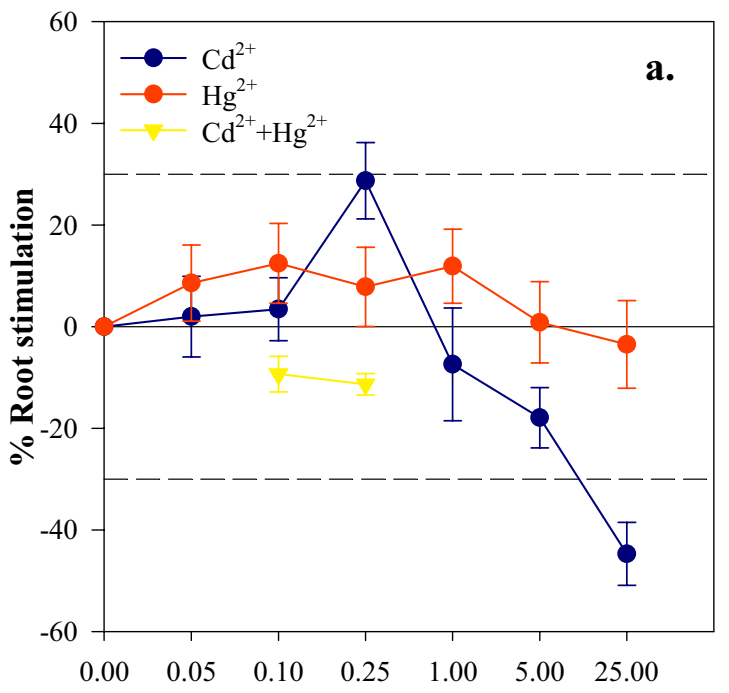

Concentration $[\mathrm{mg} / \mathrm{L}]$

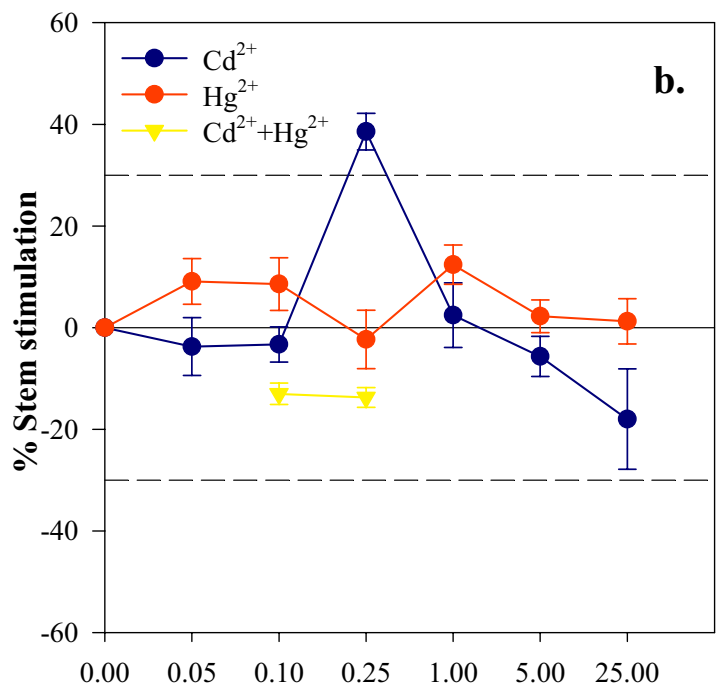

Concentration $[\mathrm{mg} / \mathrm{L}]$

Figure 3. Dose response curve of $\mathrm{Cd}^{2+} \mathrm{Hg}^{2+}$ and $\mathrm{Cd}^{2+}-\mathrm{Hg}^{2+}$ in elongation of L. perenne (a) root stimulation (b) stem stimulation.

The behavior observed in the case of $\mathrm{Cd}^{2+}$ can be based on a hormetic process of dose response, where at low concentrations a stimulus occurs in the plant, and at higher concentrations an adverse effect occurs ${ }^{43}$. These percentages of stimulation found were similar to those reported in multiple toxicology databases ${ }^{43}$. Calabrese and Blain ${ }^{44}$ indicated that the magnitude of the stimulatory response is characterized by being moderate, being in most cases between 30 and $60 \%$ above the control values.

Accordingly, the maximum level with no observable effect (NOEL) was that corresponding to the concentration of $0.1 \mathrm{mg} / \mathrm{L}$ for the early growth of the root and stem in the treatments with $\mathrm{Cd}^{2+}$. The importance of NOEL is because at this dose the stimulations in the metabolism of plant organs begin to appear, allowing a favorable effect on elongation to be achieved at higher doses. This stimulation in the metabolism could be characterized by overcompensation to an interruption in the homeostasis of the organism ${ }^{45}$. This overcompensation may be the result of incentive of cell proliferation, which could be related to the ability of $\mathrm{Cd}^{2+}$ to replace the functional metal $\mathrm{Zn}^{2+}$, allowing the binding of multiple transcription factors to the regulatory regions of genes ${ }^{46}$. The negative effects at high concentrations presented in $\mathrm{Cd}^{2+}$ for this study are very similar to those reported by other authors, because it is considered highly toxic $\mathrm{c}^{28,40,42,47-49}$, while at low concentrations positive effects similar to other studies were presented ${ }^{45,46,50,51}$. This could explain that plants develop oxidative stress when exposed to heavy metals that can cause cellular damage, due to the accumulation of metal ions that generate disturbances in cellular ionic homeostasis ${ }^{52}$.

Regarding the mixture $\mathrm{Cd}^{2+}-\mathrm{Hg}^{2+}$ the inhibition percentages were between 37.8 and $53.3 \%$, presenting the greatest negative effect for the concentration of $0.25 \mathrm{mg} / \mathrm{L}$. In the treatments of both mixtures, an inhibitory response increased with increasing concentration and was greater for the root structure which can be attributed to the mobility of metals from roots to stem and direct contact with the root surface. This shows that in L. perenne as in other plants, heavy metals tend to be retained in the root tissues, therefore, the mixing effects are generally greater in the roots than in the stem ${ }^{21,53}$. On the other hand, in the binary mixture the most pronounced antagonistic effect was presented, which may be a consequence of the interaction between the metals that results in the formation of metal complexes with greater toxicity or also the influence that a metal generates in the binary mixtures in the absorption of the other metal in the solution ${ }^{38,42}$.

In the case of $\mathrm{Hg}^{2+}$, the absorption could produce serious damage to plants by affecting chlorophyll synthesis and reducing photosynthesis as a result of the replacement of $\mathrm{Mg}^{2+}$ by $\mathrm{Hg}^{2+}{ }^{4}$. However, in the present study it was found that there was no inhibitory or stimulating response for any of the $\mathrm{Hg}^{2+}$ concentrations ${ }^{55}$. This because the absence of an inhibitory effect has been proven on growth of young tissue, which is little affected by increasing concentrations of $\mathrm{Hg}^{2+}$. Similarly, it has been found that young plant tissue, which is still in the growth stage, has the possibility of internally diluting $\mathrm{Hg}^{2+}$ concentrations by increasing biomass ${ }^{56,57}$.

Changes in gene expression of $L$. perenne. The evaluation of the genetic expression was performed by RT-qPCR, nevertheless, the specificity of the amplification was corroborated by melting curve and agarose electrophoresis. For the relative quantification the constitutive gen selected was TBP-1, in order to corroborate the viability of this selection, the $\mathrm{C}_{\mathrm{T}}$ variation among the treatments was evaluated by analysis of variance using the general linear model finding not differences neither roots nor stems among the treatments (Fig. 4) ( $P$ value $>0.05$ for the metals, plant structure, and concentrations), which indicates that this gene is suitable to be used as a gene for reference in relative quantification. 


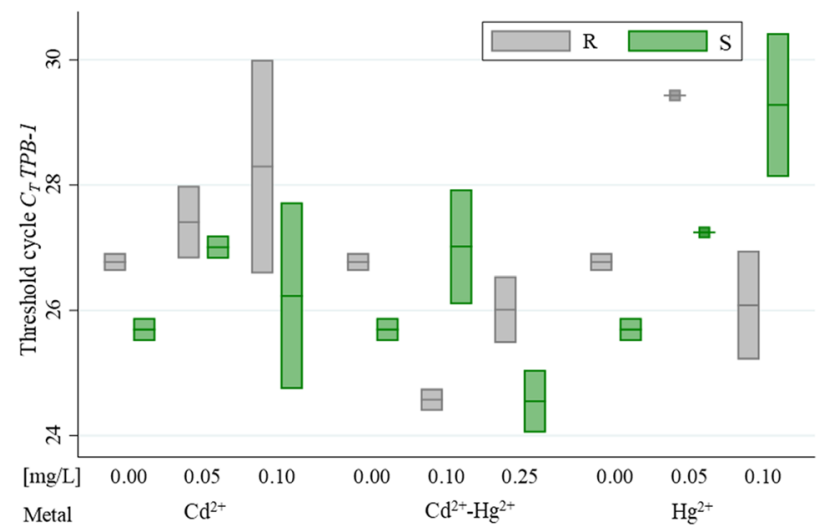

Figure 4. Mean of $C_{T}$ for the gen TBP-1 of L. perenne exposed to de different treatments (R: root and S: stem).

Differential $L$. perenne gene expression in response to different treatments. The relative expression of genes encoding for different categorical routes was evaluated for roots and stems, the magnitude of this expression changes (fold) it is shown in Fig. 5. For the detoxification response, the gen CAT (Fig. 5a) was upregulated in the stems for the three different treatments having the highest relative expression when the plant was contaminated with the $\mathrm{Hg}^{2+}$, in contrast to the root which has a moderated expression being even less than the reference gene in some treatments. This response is the result that the CAT activity has been associated with $\mathrm{H}_{2} \mathrm{O}_{2}$ removal and antioxidant protection in peroxisomes and organelle glyoxysomes found in the entire plant, the enzyme catalase being one of the first to be expressed when oxidative degradation occurs ${ }^{58}$. In contrast, pAPX (Fig. 5c) was overexpressed in the roots exposed to $\mathrm{Cd}^{2+}$ at the higher concentration, and for the stems and roots exposed to $\mathrm{Hg}^{2+}$ but not for $\mathrm{Cd}^{2+}+\mathrm{Hg}^{2+}$. This result is similar to the ones obtain in Alfalfa and maize roots where $P A P X$ responded by increasing activity at a moderate degree of toxicity ${ }^{59}$.

The GST gene (Fig. 5b) was downregulated in roots and stems exposed to the different treatments, especially in the different concentrations with $\mathrm{Cd}^{2+}$. However, it was evident that the treatments have an influence on the gene expression in comparison with the negative control. GST enzymes catalyze the conjugation between various xenobiotics with electrophilic centers, such as those produced by the metal ions of $\mathrm{Cd}^{2+}$ and $\mathrm{Hg}^{2+}$, and the nucleophile glutathione (GSH), thus marking the xenobiotic for vacuolar sequestration ${ }^{60,61}$. The resulting GSH conjugates are generally less toxic and more soluble in water than the original xenobiotics ${ }^{62,63}$.

In the category stress-related genes, the higher expression levels were for the HSP70 (Fig. 5e), it was upregulated in stems especially exposed with $\mathrm{Cd}^{2+}-\mathrm{Hg}^{2+}$ and $\mathrm{Hg}^{2+}$ at the higher concentrations, however, the expression in the roots did not show a dose response behavior. Hsp70 proteins are crucial as molecular chaperones that inflict the catalysis necessary to rapidly recruit and release proteins $s^{27,64}$. This protein has been found to play an important role in the programmed cell death of the leaves of the species Aponogeton madagascariensis, this in order to achieve the elimination of cells compromised with stress. The $H s p 90$ (Fig. 5f) was only overexpressed in roots exposed with $\mathrm{Cd}^{+2}$ and the stems exposed with $\mathrm{Cd}^{2+}-\mathrm{Hg}^{2+}$ and $\mathrm{Hg}^{2+}$. $\mathrm{Hsp} 90$ proteins are responsible for safeguarding the integrity of the cell membrane when the plant organism is exposed to heavy metals, resulting in reductions in the germination rate and root length ${ }^{65}$. Finally, for the category related to energy production, Lhcb-1 (Fig. 5h) was only expressed in the stem as expected, and it was upregulated in the three treatments, nonetheless, the response was lower for the $\mathrm{Cd}^{2+}-\mathrm{Hg}^{2+}$. The gens $M T P B-1$ for detoxification (Fig. 5d) and SDHA (Fig. 5g) energy production category were not express either for the control and the different treatments. Since, just two replicates of each treatment could be made, the statistical comparisons were not performed. However, the changes expression levels observed for the genes CAT, GST, pAPX, HSP70 and HSP90 (Fig. 5) indicated physiological mechanisms used by the plant to repair the damage conferring tolerance to grow in contaminated medium with heavy metals and even enhancing their growth under concentrations that are minimal to inhibitory, being the hormetic growth evident. These results are in accordance with previous works, where it has been found that $L$. perenne is a phytoremediator plant of this type of metals ${ }^{21}$ due to its accumulative capacity, and with the evaluation of these genes it is shown that $L$. perenne can be used in soils for the removal of contaminants such as $\mathrm{Hg}$ and $\mathrm{Cd}$.

The RT-qPCR analysis showed that the relative expression levels in the root and stem of $L$. perenne for the $M T P B-1$ and $L h c b-1$ genes did not present statistical difference between the different treatments. While for the rest of the genes (CAT, $P A P X, G S T, H S P 70$ and HSP90) there was a difference in the relative expression for the concentration factor, however, for the metal exposure factor there is no statistically significant difference. In relation to the changes in the relative expression of each gene with respect to the different concentration levels, the following was observed: for the CAT gene there was a decrease in the root and stem for a concentration of $0.25 \mathrm{mg} / \mathrm{L}$, the GST gene increased in the root for all concentrations and in the stem for a concentration of $0.10 \mathrm{mg} / \mathrm{L}, p A P X$ increased in the concentration of $0.10 \mathrm{mg} / \mathrm{L}$ in the stem, while HSP 90 increased in the concentration of $0.10 \mathrm{mg} / \mathrm{L}$ in the root, and finally HSP70 increased in the concentration of $0.25 \mathrm{mg} / \mathrm{L}$ in the stem (Table 3). 

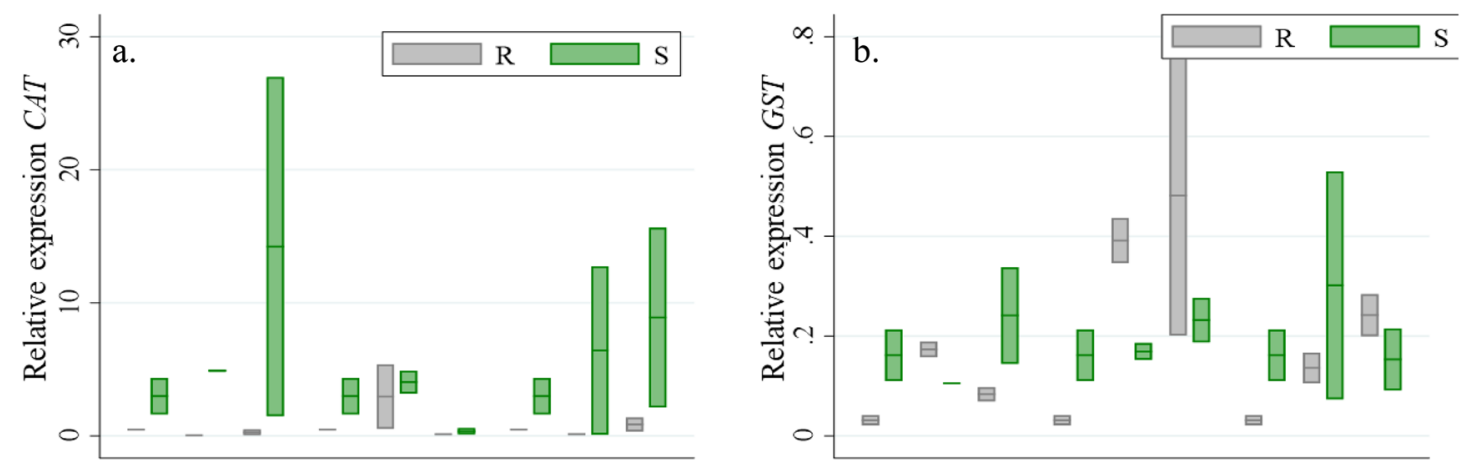

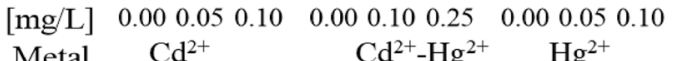
$[\mathrm{mg} / \mathrm{L}] \quad 0.000 .050 .10 \quad 0.000 .100 .25 \quad 0.000 .050 .10$

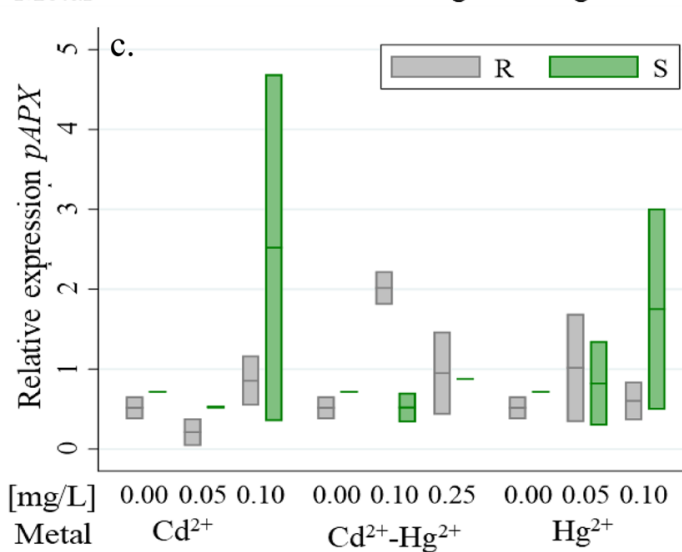

Metal $\quad \mathrm{Cd}^{2+} \quad \mathrm{Cd}^{2+}-\mathrm{Hg}^{2+} \quad \mathrm{Hg}^{2+}$
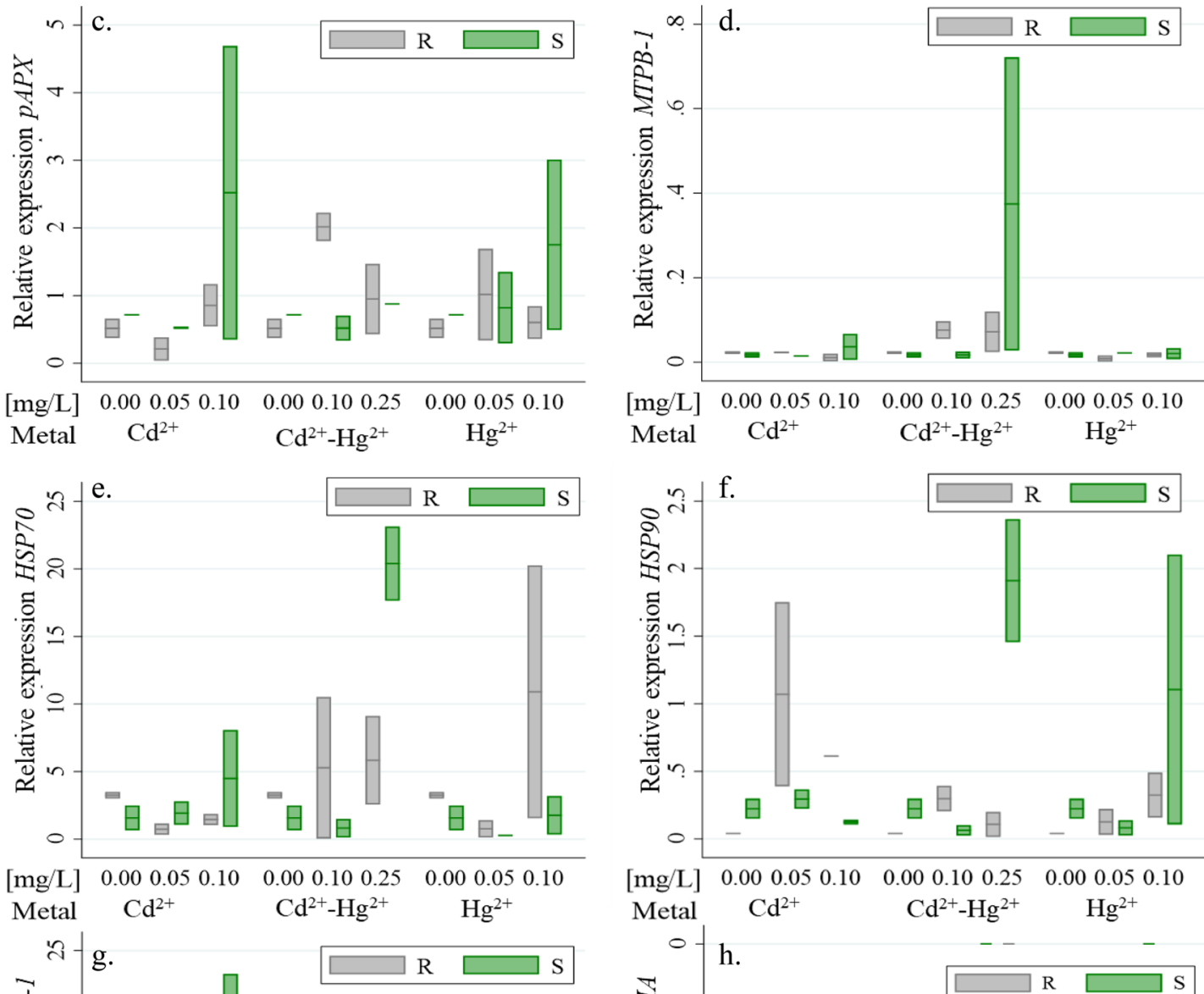

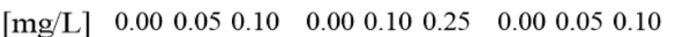
Metal $\mathrm{Cd}^{2+} \quad \mathrm{Cd}^{2+}-\mathrm{Hg}^{2+} \quad \mathrm{Hg}^{2+}$

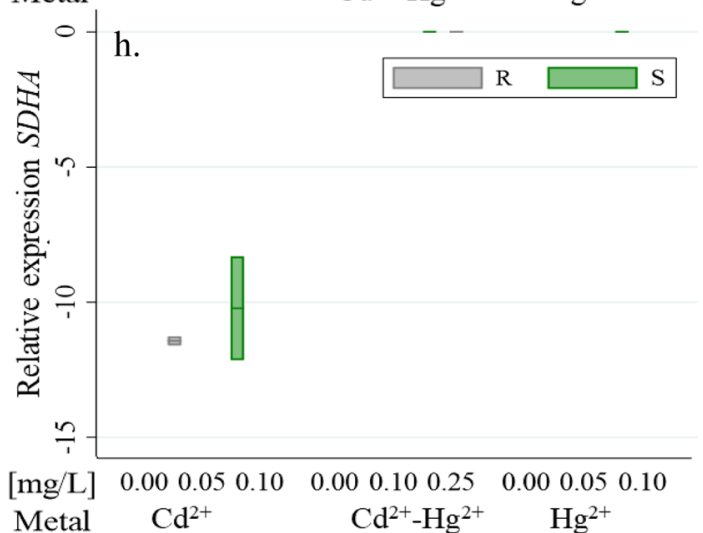

$\left[\begin{array}{llllllllll}{[\mathrm{mg} / \mathrm{L}]} & 0.00 & 0.05 & 0.10 & 0.00 & 0.10 & 0.25 & 0.00 & 0.05 & 0.10\end{array}\right.$ Metal $\mathrm{Cd}^{2+} \quad \mathrm{Cd}^{2+}-\mathrm{Hg}^{2+} \quad \mathrm{Hg}^{2+}$

Metal $\mathrm{Cd}^{2+}$

$\mathrm{Cd}^{2+}-\mathrm{Hg}^{2+} \quad \mathrm{Hg}^{2+}$

Figure 5. mean of gen relative expression in roots and stems expose for the different treatments (a) CAT, (b) GST, (c) pAPX, (d) MTPB-1, (e) HSP70, (f) HSP90, (g) SDHA, (h) Lhcb-1. (R: root and S: stem). 


\begin{tabular}{|l|l|l|l|l|l|}
\hline & \multicolumn{2}{|l|}{ Root } & \multirow{3}{*}{ Stem } \\
\cline { 2 - 3 } \cline { 5 - 6 } & Concentration $[\mathbf{m g} / \mathbf{L}]$ & $\boldsymbol{P}$-value & & Concentration $[\mathbf{m g} / \mathbf{L}]$ & $\boldsymbol{P}$-value \\
\hline CAT & $0.05-0.10$ & 0.037 & CAT & $0.05-0.10$ & 0.019 \\
\hline GST & $0.05-0.10-0.25$ & 0.000 & pAPX & 0.10 & 0.009 \\
\hline HSP90 & 0.10 & 0.015 & GST & $0.05-0.10-0.25$ & 0.020 \\
\hline & & & HSP70 & 0.25 & 0.047 \\
\hline
\end{tabular}

Table 3. Significantly different concentration levels for the expression of each gene in the root and stem structures of L. perenne.

\section{Conclusions}

The results of this study indicated that $L$. perenne is a plant with a significant phytoremediator capacity for heavy metals as $\mathrm{Cd}^{2+}$ and $\mathrm{Hg}^{2+}$ individually, since the effects at the morphological and molecular levels indicating the presence of tolerance mechanisms observed in the germination and elongation of the roots and stems. However, for the treatment $\mathrm{Cd}^{2+}-\mathrm{Hg}^{2+}$, the significant inhibition in the germination and elongation were observed and low levels of gen expression, suggesting that the phytoremediation potential may be affected if metal mixtures are found in the medium. Regarding the morphological response of the individual metals, it was found that germination presented an inhibition response relative to increasing concentration. Nevertheless, the plant grows, and an important germination percentage was obtained.

The NOEL concentration for $\mathrm{Cd}^{2+}$ was $0.10 \mathrm{mg} / \mathrm{L}$, in this concentration the longitude increases in both roots and stems, and the change of the genetic expression was observed. This could indicate this level of exposure is where the molecular tolerance response occurs in which the plant seeks to counteract the stress caused by metals mainly performed by detoxification mechanisms, which would be an explanation for the increase in morphological response at the subsequent concentration of $0.25 \mathrm{mg} / \mathrm{L}$. Even though the selection of concentrations occurred as a result of the dose response curve found for $\mathrm{Cd}^{2+}$, the molecular response was similar for this metal and for $\mathrm{Hg}^{2+}$. Indicating the detoxication molecular rout for this metal has a different morphological response.

Although the limited number of biological replicas did not allow made statistical comparisons among levels of gen expression, changes were observed, these results being a starting point for further investigation of the molecular mechanisms of phytoremediation plants, and their potential use.

Received: 3 July 2020; Accepted: 17 May 2021

Published online: 27 May 2021

\section{References}

1. Arnous, M. O. \& Hassan, M. A. A. Heavy metals risk assessment in water and bottom sediments of the eastern part of Lake Manzala, Egypt, based on remote sensing and GIS. Arab. J. Geosci. https://doi.org/10.1007/s12517-014-1763-6 (2015).

2. Calao, C. R. \& Marrugo, J. L. Efectos genotóxicos en población humana asociados a metales pesados en la región de La Mojana, Colombia, 2013. Biomedica https://doi.org/10.7705/biomedica.v35i0.2392 (2015).

3. Jaskulak, M., Grobelak, A., Grosser, A. \& Vandenbulcke, F. Gene expression, DNA damage and other stress markers in Sinapis alba L. exposed to heavy metals with special reference to sewage sludge application on contaminated sites. Ecotoxicol. Environ. Saf. 181, 508-517 (2019).

4. Kumar, R. et al. Detoxification and tolerance of heavy metals in plants. Plant Metal Interact.: Emerg. Remediat. Tech. https://doi. org/10.1016/B978-0-12-803158-2.00013-8 (2015).

5. Hu, Y. et al. Assessing heavy metal pollution in the surface soils of a region that had undergone three decades of intense industrialization and urbanization. Environ. Sci. Pollut. Res. https://doi.org/10.1007/s11356-013-1668-z (2013).

6. Zhu, D., Wei, Y., Zhao, Y., Wang, Q. \& Han, J. Heavy metal pollution and ecological risk assessment of the agriculture soil in Xunyang mining area, Shaanxi Province, Northwestern China. Bull. Environ. Contam. Toxicol. https://doi.org/10.1007/s00128018-2374-9 (2018).

7. Liu, Y., Su, C., Zhang, H., Li, X. \& Pei, J. Interaction of soil heavy metal pollution with industrialisation and the landscape pattern in Taiyuan city, China. PLoS ONE https://doi.org/10.1371/journal.pone.0105798 (2014).

8. Jan, T. A. et al. Heavy metals and human health: mechanistic insight into toxicity and counter defense system of antioxidants. Int. J. Mol. Sci. 16, 29592-29630 (2015).

9. García, J. C. C., Morales, J. P. A. \& Paredes, D. M. Evaluación del contenido de mercurio en suelos y lechos de quebradas en la zona minera de Miraflores, Quinchía, Colombia. Acta Agronómica 64, 165-177 (2015).

10. Gu, Y.-Y. \& Yeung, A. T. Desorption of cadmium from a natural Shanghai clay using citric acid industrial wastewater. J. Hazard. Mater. 191, 144-149 (2011).

11. Peláez-Peláez, M.-J., Bustamante-Cano, J.-J. \& Gómez-López, E.-D. Presencia de cadmio y plomo en suelos y su bioacumulación en tejidos vegetales en especies de brachiaria en el Magdalena Medio colombiano. Luna Azul https://doi.org/10.17151/luaz.2016. 43.5 (2016).

12. Smolders, E. Revisiting and updating the effect of phosphorus fertilisers on cadmium accumulation in european agricultural soils. In Proceedings 724 (2013).

13. Camargo García, J. C., Arias Morales, J. P. \& Muñoz Paredes, D. Evaluación del contenido de mercurio en suelos y lechos de quebradas en la zona minera de Miraflores, Quinchía, Colombia. Acta Agron. https://doi.org/10.15446/acag.v64n2.40639 (2014).

14. Ali, H., Khan, E. \& Sajad, M. A. Phytoremediation of heavy metals-concepts and applications. Chemosphere https://doi.org/10. 1016/j.chemosphere.2013.01.075 (2013).

15. Marques, A. P. G. C., Rangel, A. O. S. S. \& Castro, P. M. L. Remediation of heavy metal contaminated soils: phytoremediation as a potentially promising clean-up technology. Crit. Rev. Environ. Sci. Technol. 39, 622-654 (2009).

16. Hannaway, D. et al. Perennial ryegrass (Lolium perenne L.) (1999).

17. Nandula, V. K., Giacomini, D. A., Lawrence, B. H., Molin, W. T. \& Bond, J. A. Resistance to clethodim in Italian ryegrass (Lolium perenne ssp. multiflorum) from Mississippi and North Carolina. Pest Manag. Sci. https://doi.org/10.1002/ps.5650 (2020). 
18. Cruz, Y., Carmago, G., Gallego, J. L. \& Saldarriaga, J. F. A kinetic modelling of the growth rate of Lolium perenne for phytotoxicity bioassays. Chem. Eng. Trans. 74, 1441-1446 (2019).

19. Inostroza-Blancheteau, C. et al. Physiological and biochemical responses to manganese toxicity in ryegrass (Lolium perenne L.) genotypes. Plant Physiol. Biochem. 113, 89-97 (2017).

20. Malschi, D. et al. Phytoextraction of heavy metals from industrially polluted zone using Lolium perenne and lemna minor. Environ. Eng. Manag. J. 15, 1103-1108 (2013).

21. Leudo, M. A., Cruz, Y., Montoya-Ruiz, C., Delgado, D. M. \& Saldarriaga, F. J. Mercury phytoremediation with Lolium perenneMycorrhizae in contaminated soils. Sustainability 12, 3795 (2020).

22. de Figueirêdo, L. P. et al. The use of gene expression to unravel the single and mixture toxicity of abamectin and difenoconazole on survival and reproduction of the springtail Folsomia candida. Environ. Pollut. https://doi.org/10.1016/j.envpol.2018.10.077 (2019).

23. Li, H., Hu, T. \& Fu, J. Identification of genes associated with adaptation to $\mathrm{NaCl}$ toxicity in perennial ryegrass (Lolium perenne L.). Ecotoxicol. Environ. Saf. 79, 153-162 (2012).

24. Gallego, S. M. et al. Unravelling cadmium toxicity and tolerance in plants: insight into regulatory mechanisms. Environ. Exp. Bot. https://doi.org/10.1016/j.envexpbot.2012.04.006 (2012).

25. Rhee, J. S. et al. Heat shock protein (Hsp) gene responses of the intertidal copepod Tigriopus japonicus to environmental toxicants. Comput. Biochem. Physiol. C Toxicol. Pharmacol. https://doi.org/10.1016/j.cbpc.2008.07.009 (2009).

26. Hasan, M. K. et al. Responses of plant proteins to heavy metal stress-a review. Front. Plant Sci. 8, 1492 (2017).

27. Erbse, A., Mayer, M. P. \& Bukau, B. Mechanism of substrate recognition by Hsp70 chaperones. Biochem. Soc. Trans. https://doi. org/10.1042/BST0320617 (2004).

28. Al-Yemeni, M. N. Effect of cadmium, mercury and lead on seed germination and early seedling growth of Vigna ambacensis L. Indian J. Plant Physiol. 6, 147-151 (2001).

29. van Herwijnen, R. et al. Remediation of metal contaminated soil with mineral-amended composts. Environ. Pollut. https://doi. org/10.1016/j.envpol.2007.01.023 (2007).

30. Al-Ansari, F. \& Ksiksi, T. A quantitative assessment of germination parameters: the case of Crotalaria persica and Tephrosia apollinea. Open Ecol. J. 9, 13-21 (2016).

31. Poschenrieder, C., Cabot, C., Martos, S., Gallego, B. \& Barceló, J. Do toxic ions induce hormesis in plants?. Plant Sci. https://doi. org/10.1016/j.plantsci.2013.07.012 (2013).

32. Pfaffl, M. W. A new mathematical model for relative quantification in real-time RT-PCR. Nucl. Acids Res. https://doi.org/10.1093/ nar/29.9.e45 (2001).

33. Rao, X., Huang, X., Zhou, Z. \& Lin, X. An improvement of the 2(-delta delta CT) method for quantitative real-time polymerase chain reaction data analysis. Biostat. Bioinforma. Biomath. 3, 71-85 (2013).

34. Bewley, J. D., Bradford, K. J., Hilhorst, H. W. M. \& Nonogaki, H. Seeds: Physiology of Development, Germination and Dormancy (Springer, 2013).

35. Lehle, F. R. \& Putnam, A. R. Quantification of allelopathic potential of sorghum residues by novel indexing of Richards' function fitted to cumulative cress seed germination curves. Plant Physiol. https://doi.org/10.1104/pp.69.5.1212 (1982).

36. Richards, F. J. A flexible growth function for empirical use. J. Exp. Bot. https://doi.org/10.1093/jxb/10.2.290 (1959).

37. Venus, J. C. \& Causton, D. R. Plant growth analysis: the use of the Richards function as an alternative to polynomial exponentials. Ann. Bot. https://doi.org/10.1093/oxfordjournals.aob.a085673 (1979).

38. Kong, I. C. Joint effects of heavy metal binary mixtures on seed germination, root and shoot growth, bacterial bioluminescence, and gene mutation. J. Environ. Sci. China https://doi.org/10.1016/S1001-0742(12)60174-0 (2013).

39. Liu, X., Zhang, S., Shan, X. \& Zhu, Y. G. Toxicity of arsenate and arsenite on germination, seedling growth and amylolytic activity of wheat. Chemosphere https://doi.org/10.1016/j.chemosphere.2005.01.088 (2005).

40. Vijayaragavan, J. et al. Toxic effect of cadmium on seed germination, growth and biochemical contents of cowpea (Vigna unguiculata L.) plants. Int. Multidiscip. Res. J. 1, 1-6 (2011).

41. Balarynová, J. \& Fellner, M. Expression of genes encoding PIP aquaporins in tomato seeds exposed to blue radiation and mercury. Biol. Plant. https://doi.org/10.32615/bp.2019.001 (2019).

42. Peralta-Videa, J. R. et al. Effect of mixed cadmium, copper, nickel and zinc at different $\mathrm{pHs}$ upon alfalfa growth and heavy metal uptake. Environ. Pollut. https://doi.org/10.1016/S0269-7491(02)00105-7 (2002).

43. Mattson, M. P. \& Calabrese, E. J. Hormesis: a revolution in biology, toxicology and medicine. Hormesis https://doi.org/10.1007/ 978-1-60761-495-1 (2010).

44. Calabrese, E. J. \& Blain, R. The occurrence of hormetic dose responses in the toxicological literature, the hormesis database: an overview. Toxicol. Appl. Pharmacol. https://doi.org/10.1016/j.taap.2004.06.023 (2005).

45. Aina, R. et al. Thiol-peptide level and proteomic changes in response to cadmium toxicity in Oryza sativa L. roots. Environ. Exp. Bot. https://doi.org/10.1016/j.envexpbot.2006.04.010 (2007).

46. Sobkowiak, R. \& Deckert, J. Cadmium-induced changes in growth and cell cycle gene expression in suspension-culture cells of soybean. Plant Physiol. Biochem. https://doi.org/10.1016/S0981-9428(03)00101-3 (2003).

47. Greger, M. \& Ögren, E. Direct and indirect effects of $\mathrm{Cd}^{2+}$ on the photosynthesis and $\mathrm{CO}_{2}$-assimilation in sugar beets (Beta vulgaris). Physiol. Plant 83, 129-135 (1991).

48. Hasan, S. A., Fariduddin, Q., Ali, B., Hayat, S. \& Ahmad, A. Cadmium: toxicity and tolerance in plants. J. Environ. Biol. https:// doi.org/10.1016/c2017-0-02050-5 (2009)

49. Rubio, M. I., Escrig, I., Martínez-Cortina, C., López-Benet, F. J. \& Sanz, A. Cadmium and nickel accumulation in rice plants. Effects on mineral nutrition and possible interactions of abscisic and gibberellic acids. Plant Growth Regul. https://doi.org/10.1007/BF000 25217 (1994).

50. Arduini, I., Masoni, A., Mariotti, M. \& Ercoli, L. Low cadmium application increase miscanthus growth and cadmium translocation. Environ. Exp. Bot. https://doi.org/10.1016/j.envexpbot.2004.01.001 (2004).

51. Liu, J. et al. Interaction of $\mathrm{Cd}$ and five mineral nutrients for uptake and accumulation in different rice cultivars and genotypes. Field Crops Res. https://doi.org/10.1016/S0378-4290(03)00077-7 (2003).

52. Kunjam, M., Govada, H., Mididoddi, N. \& Sln, R. Studies on selected heavy metals on seed germination and plant growth in pea plant (Pisum sativum) grown in solid medium. J. Pharmacogn. Phytochem. 3, 85-87 (2015).

53. An, Y. J., Kim, Y. M., Kwon, T. I. \& Jeong, S. W. Combined effect of copper, cadmium, and lead upon Cucumis sativus growth and bioaccumulation. Sci. Total Environ. https://doi.org/10.1016/j.scitotenv.2004.01.002 (2004).

54. Lavado, R. S., Rodríguez, M., Alvarez, R., Taboada, M. A. \& Zubillaga, M. S. Transfer of potentially toxic elements from biosolidtreated soils to maize and wheat crops. Agric. Ecosyst. Environ. 118, 312-318 (2007).

55. Suszcynsky, E. M. \& Shann, J. R. Phytotoxicity and accumulation of mercury in tobacco subjected to different exposure routes. Environ. Toxicol. Chem. https://doi.org/10.1002/etc.5620140108 (1995).

56. de Temmerman, L., Vandeputte, R. \& Guns, M. Biological monitoring and accumulation of airborne mercury in vegetables. Environ. Pollut. Ser. Ecol. Biol. https://doi.org/10.1016/0143-1471(86)90089-9 (1986).

57. Panda, K. K., Lenka, M. \& Panda, B. B. Monitoring and assessment of mercury pollution in the vicinity of a chloralkali plant. II plant-availability, tissue-concentration and genotoxicity of mercury from agricultural soil contaminated with solid waste assessed in barley (Hordeum vulgare L.). Environ. Pollut. https://doi.org/10.1016/0269-7491(92)90114-P (1992). 
58. Hertwig, B., Streb, P. \& Feierabend, J. Light dependence of catalase synthesis and degradation in leaves and the influence of interfering stress conditions. Plant Physiol. https://doi.org/10.1104/pp.100.3.1547 (1992).

59. Rellán-Álvarez, R., Ortega-Villasante, C., Álvarez-Fernández, A., Campo, F. F. D. \& Hernández, L. E. Stress responses of Zea mays to cadmium and mercury. Plant Soil https://doi.org/10.1007/s11104-005-3900-1 (2006).

60. Martinoia, E., Grill, E., Tommasini, R., Kreuz, K. \& Amrhein, N. ATP-dependent glutathione S-conjugate 'export' pump in the vacuolar membrane of plants. Nature https://doi.org/10.1038/364247a0 (1993).

61. Xi, Y., Jiao, W., Cao, J. \& Jiang, W. Effects of chlorogenic acid on capacity of free radicals scavenging and proteomic changes in postharvest fruit of nectarine. PLoS ONE https://doi.org/10.1371/journal.pone.0182494 (2017).

62. Brown, H. M. \& Neighbors, S. M. Soybean metabolism of chlorimuron ethyl: physiological basis for soybean selectivity. Pestic. Biochem. Physiol. https://doi.org/10.1016/0048-3575(87)90068-X (1987).

63. Dixon, D. P., Davis, B. G. \& Edwards, R. Functional divergence in the glutathione transferase superfamily in plants: identification of two classes with putative functions in redox homeostasis in Arabidopsis thaliana. J. Biol. Chem. https://doi.org/10.1074/jbc. M202919200 (2002).

64. Mayer, M. P. \& Bukau, B. Hsp70 chaperones: cellular functions and molecular mechanism. Cell. Mol. Life Sci. 62, 670-684 (2005).

65. Song, H. M., Wang, H. Z. \& Xu, X. B. Overexpression of AtHsp90.3 in Arabidopsis thaliana impairs plant tolerance to heavy metal stress. Biol. Plant. https://doi.org/10.1007/s10535-012-0042-1 (2012).

\section{Acknowledgements}

This work was carried out with financial support from the Department of Civil and Environmental Engineering at Universidad de los Andes. Yuby Cruz is grateful for the M.Sc. grant from the Early-Stage Research Found -FAPA- (P3.2017.3830). Carolina Montoya-Ruiz thanks at Universidad de los Andes for her postgraduate Grant.

\section{Author contributions}

Y.C.: Investigation, Data curation, Writing- Original draft preparation. S.V.: Investigation, Data curation. K.G.: Investigation, Data Curation. C.M.-R.: Methodology, Formal Analysis, Supervision, Validation, Writing- Reviewing and Editing. J.L.G.: Writing- Reviewing and Editing. M. del P.D.: Methodology, Supervision, Writing- Reviewing and Editing. J.F.S.: Methodology, Data curation, Investigation, Supervision, Validation, Writing- Reviewing and Editing.

\section{Competing interests}

The authors declare no competing interests.

\section{Additional information}

Correspondence and requests for materials should be addressed to J.F.S.

Reprints and permissions information is available at www.nature.com/reprints.

Publisher's note Springer Nature remains neutral with regard to jurisdictional claims in published maps and institutional affiliations.

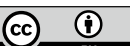

Open Access This article is licensed under a Creative Commons Attribution 4.0 International License, which permits use, sharing, adaptation, distribution and reproduction in any medium or format, as long as you give appropriate credit to the original author(s) and the source, provide a link to the Creative Commons licence, and indicate if changes were made. The images or other third party material in this article are included in the article's Creative Commons licence, unless indicated otherwise in a credit line to the material. If material is not included in the article's Creative Commons licence and your intended use is not permitted by statutory regulation or exceeds the permitted use, you will need to obtain permission directly from the copyright holder. To view a copy of this licence, visit http://creativecommons.org/licenses/by/4.0/.

(C) The Author(s) 2021 